\title{
THE RESEARCH OF ACOUSTIC EMISSION OF A LOW-POWER AIRCRAFT ENGINE
}

\author{
Michał Gęca, Konrad Pietrykowski, Karol Rosiński \\ Department of Thermodynamics, Fluid Mechanics and Aviation Propulsion Systems \\ Faculty of Mechanical Engineering, Lublin University of Technology \\ ul. Nadbystrzycka 36, 20-618 Lublin, Poland \\ m.geca@pollub.pl,k.pietrykowski@pollub.pl,karolrosinski25@gmail.com
}

\begin{abstract}
This paper presents the methodology and investigation of the sound power level produced by a radial piston aircraft engine operating at varied speeds. The research model aircraft engine of a maximum power of $5.5 \mathrm{~kW}$ with a two-bladed airscrew was placed on a test bend. Its sound power level was calculated from the sound pressure level measured at 9 measurement points distributed on a hemispherical surface in a confined space in line with PN-EN 3744. Mean sound power generated by the ASP FS400AR engine is $96 \mathrm{~dB}$ at idle $(2,880 \mathrm{rpm})$ and $105 \mathrm{~dB}$ at a cruising speed (4,740 rpm). Accordingly, it can be concluded that a sound level meter registered a higher sound power level at the points in front of the model aircraft engine than at the points behind it, whereas the lowest sound power level was registered directly above the engine.
\end{abstract}

Keywords: model aircraft engine, aerospace propulsion systems, sound power, noise.

\section{INTRODUCTION}

Acoustic emission includes the formation and propagation of acoustic waves in an elastic medium. An acoustic wave is also a wave that gives a sensation of hearing (sounds), i.e. an acoustic wave. A source of audible sounds are mechanical vibrations of objects. High-intensity acoustic waves known as noise are unwanted, burdensome and harmful to human health. A unit of measurement of sound pressure is the decibel $(\mathrm{dB})$ which according to the characteristics of the human ear is a non-linear quantity. In addition, noise are also propagating through air and harmful to health acoustic waves of frequencies inducing no sensation of hearing, i.e. infrasound $(2 \mathrm{~Hz}-16 \mathrm{~Hz}$ frequencies) and ultrasound $(16 \mathrm{kHz}$ $-10 \mathrm{GHz}$ frequencies). Noise growth rates are significant nowadays. Globally in every decade of the $21^{\text {st }}$ century, the noise level will increase by $1 \mathrm{~dB}[1]$ or even by $2 \mathrm{~dB}$ according to ODCE reports.

The area impacted by aircraft noise is large as it covers both areas around airports and much spacious areas of several tens of square kilometers. The issue of aircraft noise is principal because too high 
sound intensity can disrupt human physiological processes and cause, e.g. hearing loss, significant tiredness and nervous tension which can lead to high blood pressure, a heart attack or a stroke. Air traffic has an adverse impact on the environment both in terms of acoustic and exhaust emissions, which is thoroughly discussed by Kijewski [2].

The aircraft engine and the airflow around the aircraft (aerodynamic noise) are chiefly the source of noise produced by most aircraft. Sounds are produced by the airframe, particularly the airflow around the tail unit, the protracted landing gear, flaps, slots and anywhere the structure is discontinuous [3]. Authors [4] present mechanisms of silent flight of owls which may constitute bionic inspiration for aircraft designers seeking for aerodynamic noise reduction technologies.

The engine and basically the propeller are the principal sources of noise produced by respectively the turbine engine aircraft and the aircraft with an internal combustion piston engine and a propeller. Noise produced by a propeller consists of broadband and rotational noise components. Broadband noise is produced by the interaction between the turbulent flow and trailing edges of propeller blades. Propeller rotational noise is composed of fundamental and harmonic frequency tonal components. The fundamental frequency is determined by the product of the propeller rotational frequency and the number of blades. For propellers whose tips operate at supersonic velocities, two mechanisms are responsible for rotational noise. The mechanism one is the periodic flow offset caused by moving blades due to their finite thickness, the second one comes from the periodic variation of the component vector of aerodynamic forces (lift and drag) towards an observer's position. Effective local flow velocity (the sum of componential vectors of rotational and axial velocities) for a given radial blade position is the key parameter in these two types of noise source. Therefore, reasonable noise levels are essentially regulated both by blade thickness and aerodynamic forces near the blade tip. Reducing blade's Mach number is the most effective method to reduce propeller noise. This can be achieved by reducing a blade diameter while maintaining a constant engine velocity. Propeller thrust can be maintained if more blades applied. A potentially low-noise propeller should also help avoid significant loads acting on the blade [5]. More rotor and tail blades can reduce especially helicopter noise [6]. Active noise reduction inside the cabin of the aircraft can be achieved by using appropriate acoustic damping materials for the construction of the fuselage walls. Authors [7] developed vibration model of the plate made of aluminum and the plate made of carbon/epoxy composite This concept is about reducing the vibration of the fuselage walls excited by the propeller tonal noise.

The cyclic nature of piston engine operation and no silencing systems for inlet and outlet systems combined with mostly air-cooled structures can significantly affect acoustic emission while the engine operates. Mufflers are not generally installed in aircraft piston engines because rotating propellers produce much higher noise that drowns out the engine. If mufflers are installed, more exhaust gas is emitted into the cylinder after the exhaust, which has an adverse effect on engine operation. Acoustic emission in piston engines is reduced by a two-phase injection. The main injection phase is preceded by a pilot dose injection, which reduces pressure growth dynamics and has an impact on reducing engine noise.

Air-cooled aircraft engines produce more noise than liquid-cooled ones. The liquids jacket around the cylinder liner can more or less absorb and restrain the emission of noise from the combustion chamber and the cylinder [8]. Noise increases with the fourth power of the increase of engine speeds. There is no influence of the engine load on the emitted noise at higher speeds, whereas at lower engine speed influence is pronounced [9]. The noise from engine depends also on the muffler, propeller combination, as well as the airframe construction. 
Most aircraft need to be noise certified by Register of Civil Aircraft. Such noise certification certifies that the aircraft satisfies the provisions of I volume of Annex 16 to the Convention on International Civil Aviation, which is one of the necessary conditions to be satisfied to register the aircraft in the civil aircraft register and release it to service. This type of certification can be granted if the aircraft undergoes noise measurements consisting in recording the sound level according to the A characteristics and the SLOW time constant on a special test stand placed 2,500 $\mathrm{m}$ from the take-off spot and specifying its maximum value for every flight time. The experiment covers at least 6 valid flight times on the test stand [10]. In 2017, the Vibroacoustic Laboratory was opened in the Institute of Aviation's Materials and Structures Research Center. The core of the Laboratory is to provide ground vibration testing (GVT) of flying objects whose results are the basis for further dynamic analysis, in particular, flutter investigations that are required by the aviation authorities. The laboratory is able to provide a GVT's for any kind of object, also in its working conditions as environmental testing [11]. For example authors [12] from Institute of Aviation conducted measurements, which determine the gyroplane noise properties and the noise measurement methods. The rotor noise test must be carried out on a special stand whose drive is muted. The noise generated at the blade ends and is considerably smaller than that of the propeller.

This paper discusses acoustic emission produced by the aircraft low-power engine mounted in the model aircraft for sports and research applications. Low-power reciprocating internal combustion engines are largely mounted in the unmanned aircraft due to their simple construction and easy operation. Such engines are generally expected to be highly reliable, light-weight and small-sized [13]. The leaders in the production of model aircraft engine include: ASP, SAITO, DA, 3W, ZDZ, DLE. Engine capacities in such aircraft need to correspond aircraft weight. It is $6 \mathrm{~cm}^{3}$ and $9 \mathrm{~cm}^{3}$ per kilogram in the up to $9 \mathrm{~kg}$ aircraft and the $27 \mathrm{~kg}$ aircraft, respectively.

The AMA (Academy of Model Aeronautics) organizes every year National Aeromodelling Championships, the world's largest model aircraft competition. Every year flying fields are lost because people living near them do not like the noise produced by powered model aircrafts. The AMA developed a document regarding noise abatement from the model aircraft. In this document there is an example of how a professional engineering firm conducts sound studies for the purpose of measuring whether a flying field is legal according to local ordinances [14]. Rule 4.2 published by the AMA in the 2011-2012 Competition Regulations for the Radio Control Aerobatics simply states the maximum noise level for all AMA classes shall be 96 decibels measured at three 3 meters from the center line of the model [15].

Norman Carter- Chairman- Felbridge Flyers RMFC (Radio Model Flying Club) tried to find a flying site that meets the DoE guidance on distances from houses. For many years, the RMFC developed the table with the noise tested models giving details of model, engine, prop and silencer arrangement. The Committee decided that all RMFC members have to reduce maximum sound output to $81 \mathrm{dBa}$ but also a maximum ground run rpm to 10,000 for i/c powered aircraft. About $95 \%$ of member models were below $80 \mathrm{dBa}$ with significant numbers being in the $75-76 \mathrm{~dB}$ range. They use large props to keep engine speed down and the same go down with an annoyance factor [16].

The paper [17] explored noise exposure levels from model aircraft engines under $3.25 \mathrm{cc}$ and the effectiveness of engine mufflers. The authors gave suggestions for avoiding damage to hearing. The authors [17], [18] examined 1985 the noise produced by model aircraft engines for an engine capacity ranging from 0.19 to 0.46 . The acoustic analysis of model aircraft engine noise on hearing indicated that the $\mathrm{dB}$ levels exceeded damage risk criteria for short-term exposure. They recommend 
that model aircraft fliers should wear ear protection. This publications concern two-stroke glow engines and not quieter four-stroke or gasoline engines. Some of these research publications do not discuss later constructions and the binding workplace acoustic emission standards.

\section{METODOLOGY}

Sound levels were measured in line with the technical method (class 2) that requires environmental corrections according to PN-EN ISO 11201. The arrangement and number of microphones on the measurement surface are in line with PN-EN 3744, including research engine dimensions (a small source). The measurements are taken under conditions close to the free field above the reflecting plane. These conditions occur when the source of noise is located in an open space or in a large room. This method is applicable to the testing of a number of machines at their natural location of use. The measurements were performed for 10 measuring points distributed on the hemispherical surface (Figure 1). Distance $r$, or the distance between the surrounding surface and the research source for the hemispherical surface is $1 \mathrm{~m}$. This is the closest distance possible due to the construction of the test stand. It is better to adopt as small as possible a radius of the hemispherical surface to reduce the impact of a background noise. A reference rectangular is the model aircraft engine - ASP FS400AR of the following dimensions: $=27 \mathrm{~cm},=50 \mathrm{~cm},=65 \mathrm{~cm}$.

The noise was registered in line with a continuous sound level registration according to the A characteristics and a FAST time constant. The acoustic emission produced by the low-power aircraft engine was examined for two kinds of speed: idle (2 $880 \mathrm{rpm})$ and 4,740 rpm. The background noise was measured while the following equipment was operating: a supply ventilation, an exhaust ventilation with its $70 \%$ power, a lab power supply for glow plugs and lights.

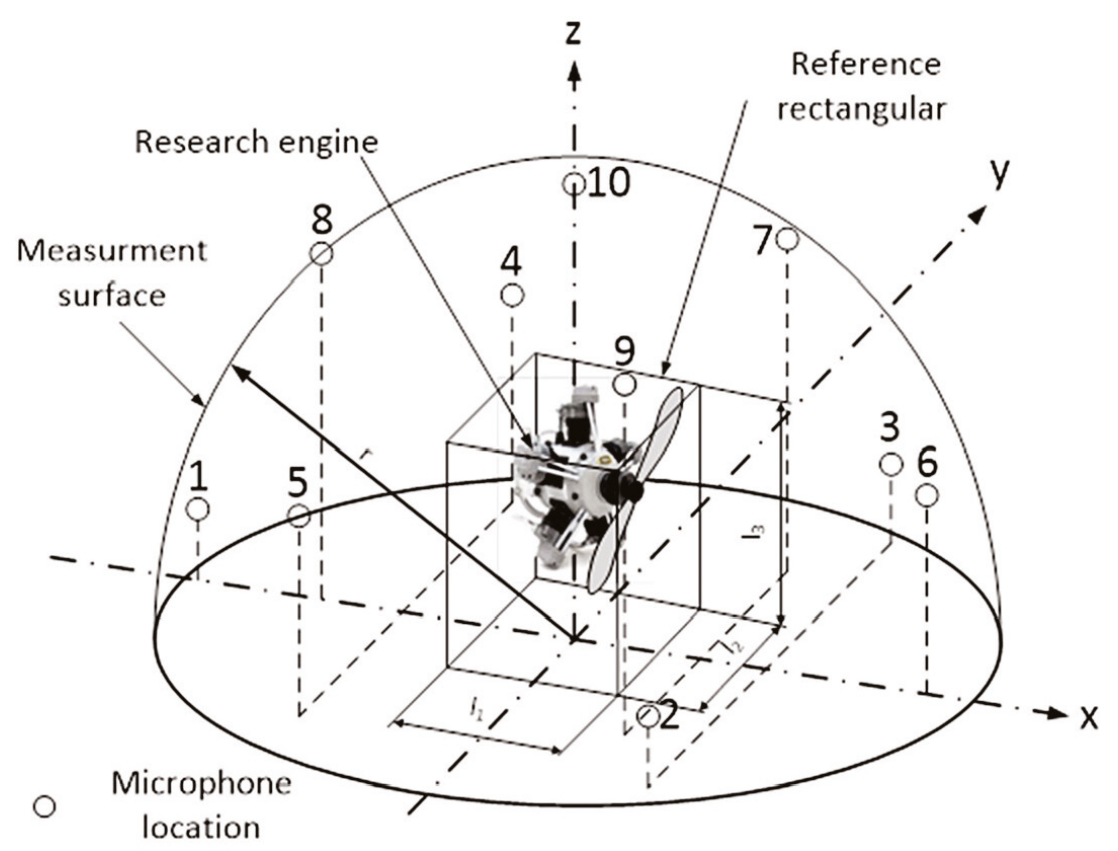

Fig. 1. Distribution of the measuring points on the hemispherical measurement surface 
On the test stand, the following parameters were specified: acoustic pressure $\overline{\mathrm{L}_{\mathrm{pf}}}$.

$$
\overline{L_{p f}}=\overline{L_{p}^{\prime}}-K_{1}-K_{2}[d B]
$$

and sound power as:

$$
L_{w}=\overline{L_{p f}}=10 \lg \left(\frac{s}{s_{0}}\right)[d B]
$$

Correction factor K1 for the background noise was included:

$$
\begin{gathered}
K_{1}=-10 \lg \left(1-10^{-0,1 \Delta L}\right)[d B] \\
\Delta L=\overline{L_{p}^{\prime}}-\overline{L_{p}^{\prime \prime}}
\end{gathered}
$$

Where

$\overline{L_{p}^{\prime}}$ - mean sound pressure on the measurement surface during the operation of the research source, $\overline{L_{p}^{\prime \prime}}$ - mean sound pressure of the background noise on the measurement surface.

Environmental factor $\mathrm{K}_{2}$ specifies deviations of a given research environment from the ideal conditions of the free field according to PN-EN ISO 3744. $\mathrm{K}_{2}$ factor for this room have the value 3,48 dB. $\mathrm{K}_{2}$ was calculated from:

$$
K_{2}=10 \lg \left[1+4\left(\frac{s}{A}\right)\right][d B]
$$

where: A- room acoustic absorption, $S$ - measurement surface area (hemispherical).

Room acoustic absorption is calculated from:

$$
A=S_{y} * \alpha_{s}\left[m^{2}\right]
$$

where: $S_{v}$ - area of the measuring room including floor $\left(138 \mathrm{~m}^{2}\right)$ $\alpha_{s}$ - average value of the acoustic absorption coefficient in the room according to table 1 . 
Tab. 1. Average value of the acoustic absorption coefficient $\alpha_{s}$

\begin{tabular}{|l|l|}
\hline Type of room & $\boldsymbol{\alpha}_{\mathbf{s}}$ \\
\hline Empty room with smooth concrete and brick walls & 0.05 \\
\hline Partially empty room with smooth concrete walls, bricks & 0.10 \\
\hline Room with hard furniture, industrial hall with technical equipment & 0.15 \\
\hline A room with a complex shape, with or without technical equipment. & 0.20 \\
\hline $\begin{array}{l}\text { Room with soft furnishings factory branch with partial acoustic adaptation and sound absorbing } \\
\text { systems on walls and ceilings }\end{array}$ & 0.25 \\
\hline Room with full acoustic adaptation on walls and ceilings & 0.35 \\
\hline Room equipped with special sound-absorbing constructions & 0.50 \\
\hline
\end{tabular}

The room houses construction elements are made of both glass and aluminum (windows), concrete (walls), steel (doors) as well as insulating elements. $\alpha_{\mathrm{s}}$ is assumed here as 0.12 .

Measurement surface area was calculated as:

$$
S=2 \cdot \pi \cdot r^{2}\left[m^{2}\right]
$$

where: $\mathrm{r}-\mathrm{a}$ radius of the hemispherical surface $(0.9 \mathrm{~m})$.

\subsection{Research engine}

The research object is a model aircraft piston engine, ASP FS400AR. Its technical parameters are given in Table 1 . This model aircraft 5-cylinder 4-stroke radial engine is a drive unit for training airframes. The radial engine is a type of aircraft combustion engine with its crankshaft mounted in the middle and its cylinders mounted on a circumference of a circle. The radial engine has become a main tool to develop aviation due to its simpler design, lower weight compared to that of an in-line engine of a similar displacement and an easier way to increase its power by multiplying the Star cylinder arrangement [19], [20]. The radial engine is mostly air-cooled. The strong point of the radial engine is its compact design, easily achieved high power while having a really low specific weight and its highly efficient air cooling. The radial aircraft engine have, however, higher drag and a large diameter making them hard install in the lightweight airframe.

The air-cooled engine has a one-piece crankcase, a dual ball bearing-supported crankshaft and camshaft, an iron ringed aluminum alloy piston and overhead "poppet" valves with a cover. Its ignition system are glow plugs permanently connected to a source of electrical power. The engine is lubricated by oil added to fuel. Fuel has additives to facilitate glow-plug ignition (Nitromethane). The engine has a rear-mounted updraft carburetor with a choke valve, which enables its installation on the airframe and making it invisible if placed with fuel ducts and a fuel tank behind the engine. 
Tab. 2. ASP FS400AR engine technical parameters [21]

\begin{tabular}{|l|l|}
\hline Power & $5.55 \mathrm{~kW}$ at $7,250 \mathrm{rpm}$ \\
\hline Displacement: & $65 \mathrm{~cm}^{3}\left(5 \times 12.8 \mathrm{~cm}^{3}\right)$ \\
\hline Bore: & $26.5 \mathrm{~mm}$ \\
\hline Stroke: & $23.2 \mathrm{~mm}$ \\
\hline RPM range & $1,800 \sim 9,000 \mathrm{rpm}$ \\
\hline Weight: & $2,800 \mathrm{~g}$ \\
\hline Glow plugs & OS Max typ „F” \\
\hline
\end{tabular}

\subsection{Test stand}

The test stand comprises the research engine with instruments needed for its operation and a framework with devices like a laboratory power supply, a speed sensor and a sound level meter to read measured values. To avoid a too high concentration of exhaust gases in a test stand room, an engine outlet system is connected to a mechanical exhaust ventilation.

The research model aircraft engine with a two-bladed airscrew was placed on a test bend. The airscrew was in the net ring during this measure and the engine was outside it. The direction of rotation was clockwise looking from point 6 and the flow was directed on the engine.

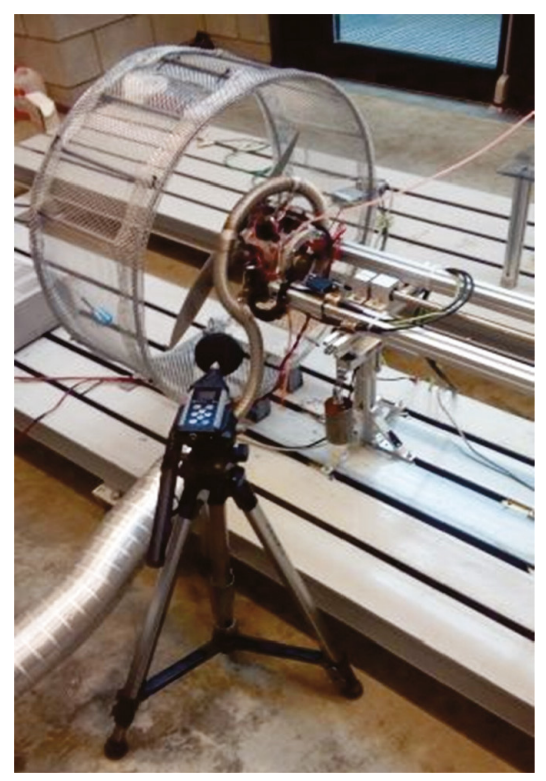

Fig. 2. Test stand with a sensor in measurement point 4

Rotational speed was measured with a laser tachometer CEM AT-6 [22]. The maximum error of this meter is as much as $0.05 \%$. The main advantage of this type of tachometer is that the construction of the test stand is not directly modified, except for sticking a reflective sticker on the propeller. 
The sound level was measured with a sound-level meter SVAN 971 SVANTEK [23]. This instrument is an extremely small class 1 digital sound level meter and analyzer. In contrast to the microphone matrix, there is a single microphone that functions as a transducer. It converts the energy of sound waves into electricity. The microphone transmits with electrical conductors information carried by a sound wave. Acoustic wave pressure makes a flexible membrane vibrate. The class 1 sound level meter complies with PN-EN 61672-1:2013. This device while measuring the sound enables an analysis in octave bands and one third octave bands. The results recorded on a mikroSD card can be transferred with the SvanPC ++ into to a computer. This software enables us to visualize and transfer data into a text document or spreadsheet.

\subsection{Results}

Having turned-on the model aircraft piston engine, the first measurements were performed at a speed of 2,880 $\mathrm{rpm}$. The measurment range covers 10 measuring points, which corresponds to ten positions of the sound level meter on the hemispherical surface. The sound level meter was placed on the previously calculated spots within an appropriate distance and height from the research engine. Figure 3 shows the measured maximum and minimum background sound pressures for a measurement point no 1 . The difference between the background sound pressure and the engine sound pressure at a speed of 2,800 rpm is $33.7 \mathrm{~dB}$. The mean sound power produced by the ASP FS400AR at idle is $96 \mathrm{~dB}$. The lowest mean sound pressure is at $16,000 \mathrm{~Hz}$ and reaches $70.7 \mathrm{~dB}$, whereas the highest one is $103.2 \mathrm{~dB}$ at $500 \mathrm{~Hz}$. Figure 4 shows that the mean sound pressure level at a speed of 2,880 rpm increases up to $500 \mathrm{~Hz}$ and then decreases but frequency increases.

The difference between the background sound pressure level and the engine sound pressure level at a speed of $4,740 \mathrm{rpm}$ reaches $42.8 \mathrm{~dB}$, whereas mean sound pressure produced by the ASP FS400AR at the same speed reaches $105 \mathrm{~dB}$.

Table 4 shows that the highest sound pressure level at the lowest shown frequency is for measuring points no 1 and 8 right behind the engine. The lowest mean sound pressure, i.e. $80 \mathrm{~dB}$ is for $16 \mathrm{kHz}$, whereas the highest mone of $102.2 \mathrm{~dB}$ is for $500 \mathrm{~Hz}$. Figure 5 shows that the mean sound pressure level increases to a frequency of $500 \mathrm{~Hz}$ if the engine operates at $4,740 \mathrm{rpm}$, which is followed by the decreased mean sound pressure and increased frequency.

Measurement points no 2, 3, 6, 7 and 9 are in front of the propellers, whereas measurement points no 1, 4, 5 and 8 are behind the engine. Figure 6 shows that the meter placed at the points in front of the engine registered higher sound power than at the points behind the engine. The minimum sound pressure was recorded for measurement point no 10, right behind the engine. The maximum and minimum sound pressures at 4,740 rpm, i.e. respectively $109 \mathrm{~dB}$ and $101.2 \mathrm{~dB}$ were registered at measurement points no 7 and 10. The highest acoustic power at idle amounted to $99.1 \mathrm{~dB}$ at measurement point no 7, whereas the lowest one was $92.6 \mathrm{~dB}$ at point no 10 . Measurement points no 2, 3 and 7 , 9 are within the same distance and at the same height but at the opposite sides of the engine. The different results at these points might be due to their distance from the other operating devices that support engine operation, e.g. the power supply for glow plugs, the supply ventilation and the exhaust ventilation operating with a $70 \%$ power. Here is a steady-state noise that occurs if changes in the sound level in time are not more than $5 \mathrm{~dB}$. 


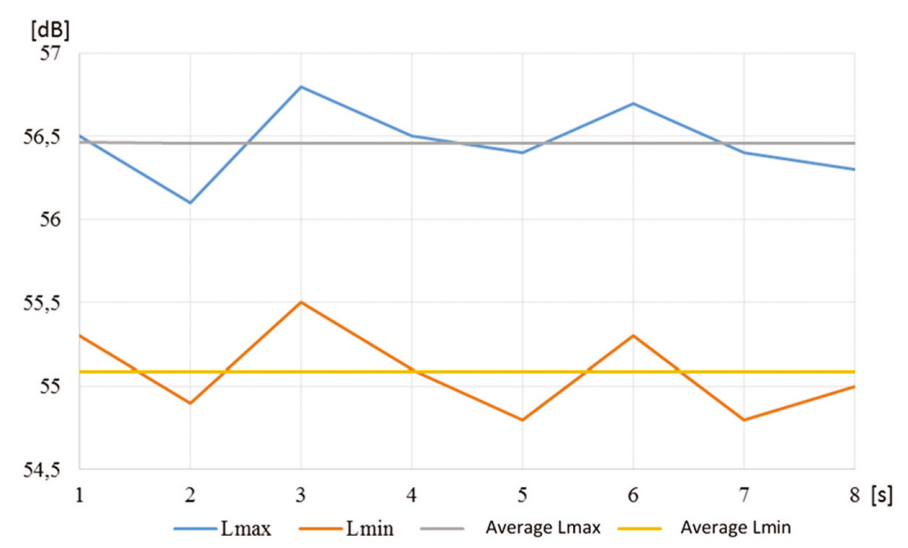

Fig. 3. Mean maximum and minimum background sound pressures for a measuring point no 1 at a speed of 2,880 rpm

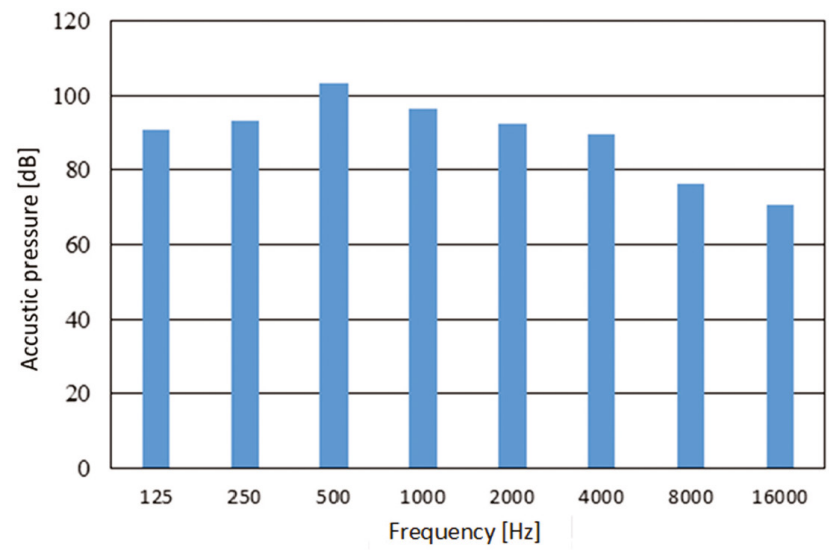

Fig. 4. Sound pressure vs. frequency at idle, i.e. 2,880 rpm

Tab. 3. Sound pressure in octave bands at a speed of 4,740 rpm

\begin{tabular}{|c|c|c|c|c|c|c|c|c|}
\hline $\begin{array}{c}\text { Microphone } \\
\text { location }\end{array}$ & $\begin{array}{c}125 \mathrm{~Hz} \\
{[\mathrm{~dB}]}\end{array}$ & $\begin{array}{c}250 \mathrm{~Hz} \\
{[\mathrm{~dB}]}\end{array}$ & $\begin{array}{c}500 \mathrm{~Hz} \\
{[\mathrm{~dB}]}\end{array}$ & $\begin{array}{c}1 \mathrm{kHz} \\
{[\mathrm{dB}]}\end{array}$ & $\begin{array}{c}2 \mathrm{kHz} \\
{[\mathrm{dB}]}\end{array}$ & $\begin{array}{c}4 \mathrm{kHz} \\
{[\mathrm{dB}]}\end{array}$ & $\begin{array}{c}8 \mathrm{kHz} \\
{[\mathrm{dB}]}\end{array}$ & $\begin{array}{c}16 \mathrm{kHz} \\
{[\mathrm{dB}]}\end{array}$ \\
\hline 1 & 90.8 & 91.3 & 102.4 & 95.3 & 97.1 & 92.6 & 80.2 & 76.0 \\
\hline 2 & 85.9 & 93.9 & 96.4 & 93.8 & 93.7 & 89.3 & 88.9 & 87.9 \\
\hline 3 & 82.4 & 95.2 & 94.6 & 98.3 & 98.6 & 97.2 & 84.6 & 83.5 \\
\hline 4 & 85.3 & 90.2 & 103.5 & 99.1 & 97.5 & 93.2 & 85.3 & 82.7 \\
\hline 5 & 84.5 & 93.5 & 101.5 & 98.1 & 93.3 & 91.6 & 86.8 & 84.6 \\
\hline 6 & 79.8 & 97.9 & 108.0 & 100.4 & 98.6 & 96.0 & 80.9 & 76.7 \\
\hline 7 & 82.1 & 92.7 & 105.3 & 99.1 & 94.8 & 89.3 & 82.9 & 78.6 \\
\hline 8 & 95.3 & 91.9 & 106.2 & 97.2 & 98.1 & 87.0 & 81.0 & 78.5 \\
\hline 9 & 81.9 & 90.3 & 103.2 & 99.7 & 94.1 & 92.8 & 81.7 & 77.6 \\
\hline 10 & 79.6 & 91.7 & 101.3 & 98.6 & 94.5 & 90.3 & 79.5 & 74.2 \\
\hline Mean & 84.8 & 92.9 & 102.2 & 98.0 & 96.0 & 91.9 & 83.2 & 80.0 \\
\hline
\end{tabular}




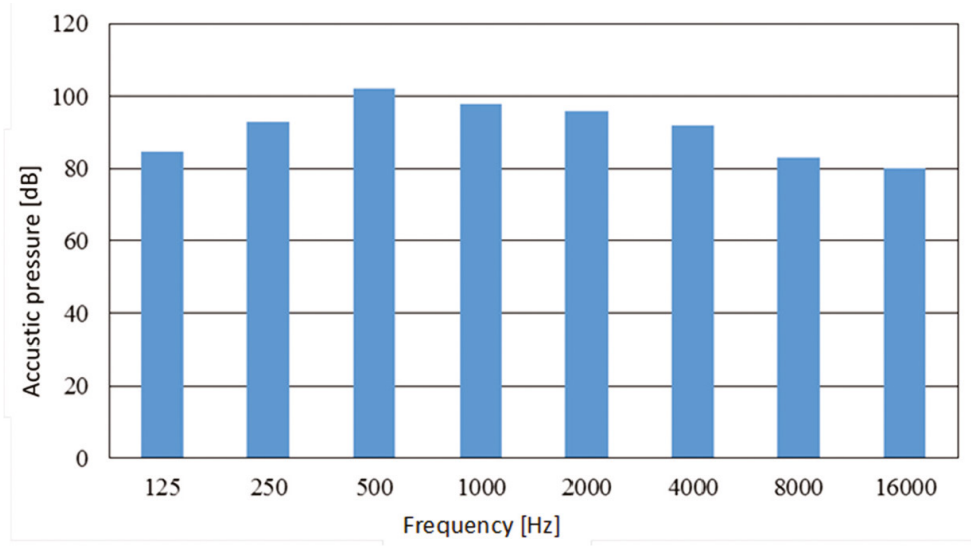

Fig. 5. Sound pressure vs. frequency at 4,740 rpm

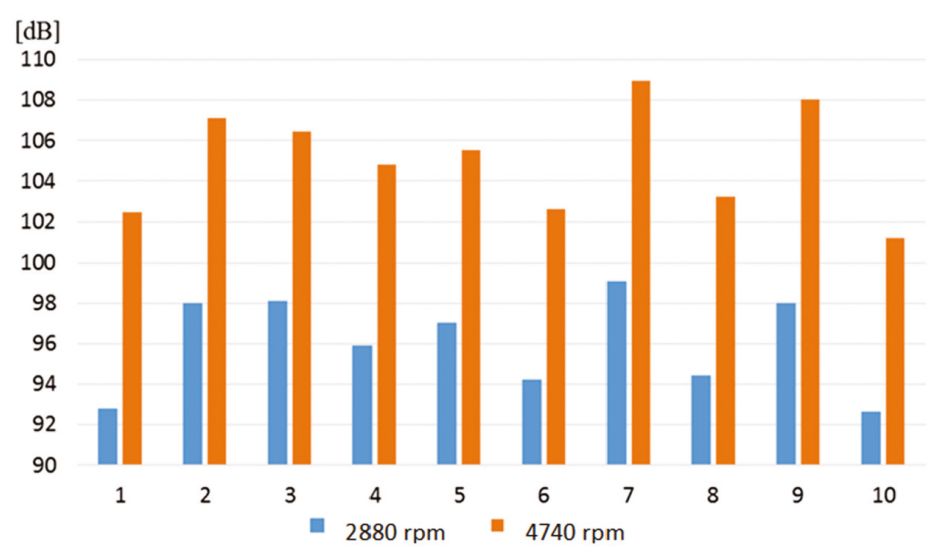

Fig. 6. Sound pressure at the 10 measuring points

\section{SUMMARY}

Sound pressure was measured for two different speeds of the model aircraft engine, i.e. idling and cruising speed. The mean sound pressure level produced by the ASP FS400AR at idle, i.e. 2,880 rpm is $96 \mathrm{~dB}$ and at a cruising speed, i.e. 4,740 rpm is $105 \mathrm{~dB}$. These research results are slightly different from Bessa's and Powell's ones. The mean sound power of the ASP FS400AR amounts to $105 \mathrm{~dB}$, whereas the sound power registered by these researchers ranges from 106 to $114 \mathrm{~dB}$.

The meter placed at the measurement points in front of the engine registered higher sound power than at the points behind the piston engine. The minimum sound pressure was registered directly above the engine. The mean sound power increases up to a frequency of $500 \mathrm{~Hz}$ and then decreases along with increasing frequency. The highest sound pressure at the lowest frequencies occurs right behind the engine.

It is recommendable to examine such an engine for other speeds and verify that assumption by measuring those parameters for open and closed, i.e. a measuring room, spaces and by checking the difference between the results.

Here, a two-bladed propeller was mounted on the research radial piston engine so if a different type of propeller is mounted, sound power can be different, which also should be verified. 
The acoustic emission registered in the research engine enables us to determine certain requirements regarding a design of sound-absorbing partitions for a test stand and to determine such working conditions to satisfy safety standards or correctly assess workers' exposure to noise.

\section{REFERENCES}

[1] Mazur, E., 2000: Hazards to the natural environment and economic and legal aspects of its protection (Zagrożenia środowiska przyrodniczego a ekonomiczno-prawne aspekty jego ochrony). Uniwersytet Szczeciński, Szczecin.

[2] Kijewski, T., 2002: „Aircraft and environment - noise and exhaust emissions” („Samolot a środowisko - hałas i emisja spalin”), Ph.D. thesis, Wydział Budowy Maszyn i Lotnictwa, Politechnika Rzeszowska.

[3] Szczeciński, S., 2009: Aircraft power units (Lotnicze zespoły napędowe), WAT, Warszawa.

[4] Cieślak, M., Rojek, M., 2013: „Owls' silent flight inspires aerodynamic aircraft noise reduction” („Cichy lot sów inspiracją do redukcji aerodynamicznego hałasu lotniczego”), Prace Instytutu Lotnictwa, 229, 55-110.

[5] Muller, G., Moser, M., 2013: Handbook of Engineering Acoustics, Springer.

[6] Golon, G., 2008: „The analysis of the possibilities of helicopter noise decrease on the example of PZL W3 FALCON helicopter” (“Analiza możliwość zmniejszenia hałasu śmigłowca na przykładzie PZL W3 Sokół”), Prace Instytutu Lotnictwa, 194-195, pp. 251-255.

[7] Szmidt, M., 2013: "Analitycal vibration plate model with acoustic excitation" ("Model drganiowy laminowanej płyty poddanej wymuszeniu akustycznemu”), Prace Instytutu Lotnictwa, 229, pp. 3-25

[8] Šubic, J., Čudina, M., Trenc, F., Želežič, E., 1997: “Influence of Cylinder Cooling on Engine Noise Emission”. Strojniški vestnik - Journal of Mechanical Engineering, 43.

[9] White, R. G. and Walker, J. G., 1986: Noise and vibration. Ellis Horwood Limited, New York.

[10] Kalina, P., 2011: "External noise measurement of propeller airplanes by FAR 36 Appendix G and annex 16 Chapter 10 of ICAO Convention” („Pomiar hałasu zewnętrznego samolotów śmigłowych wg przepisów FAR 36 Appendix G oraz Rozdziału 10 Załącznika 16 Konwencji ICAO”), Prace Instytutu Lotnictwa, 221, pp. 109 - 114.

[11] www.ulc.gov.pl, access: 05.2018.

[12] Cieślak, S., Krzymień, W., 2018: “Drivetrain noise of the Gyroplane I-28” („Hałas układu napędowego wiatrakowca I-28”), Prace Instytutu Lotnictwa, 1(250), pp. 7-15.

[13] Dzierżanowski, P., 1981: Reciprocating engines series aviation propulsion systems (Silniki Ttokowe serii Napedy lotnicze), WKt, Warszawa.

[14] http://www.modelaircraft.org, access: 05.2018.

[15] Academy of Model Aeronautics, Competition regulations 2011-2012 rules governing model aviation competition in the united states radio control aerobatics. (2011, 01) from http://www. modelaircraft.org/files/2011-2012RCAerobatics2.pdf, access: 05.2018.

[16] Carter, N., 2016 "Noise Reduction Chart- Felbridge Flyers RMFC from http://www.flyingsites. co.uk/howto/noisechart.htm.

[17] Pearlman, R. C., Miller M. Jr., 1985: “Noise Exposure Levels from Model Airplane Engines”, J Aud Res., 25, pp. 27-30.

[18] Bess, F.H., Powell, R.L., 1972: "Hearing hazard from model airplanes", Clincal Pediatrics, 11, pp. 621-624. 
[19] Werner, J., Wajand, J., 1983: Low-mid power internal combustion engines (Silniki spalinowe matej średniej mocy), WNT, Warszawa.

[20] Dobrowolski, M., Budniak, Z., 2014: „Modeling radial engine” („Modelowanie silnika gwiazdowego"), Autobusy: technika, eksploatacja, systemy transportowe, 6, pp. 100-103.

[21] „ASP FS400AR engine specification” from www.nastik.pl, access: 18.05.2018

[22] "CEM AT-6 tachmometer specification" from www.multiproject.pl, access: 18.05.2018

[23] "SVAN 971 Sound Level Meter Specification" from www.svantek.com, access: 18.05.2018

\section{BADANIE EMISJI AKUSTYCZNEJ LOTNICZEGO SILNIKA MAŁEJ MOCY}

\section{Streszczenie}

W artykule przedstawiono metodologię oraz badania emisji akustycznej tłokowego lotniczego silnika w układzie gwiazda przy określonych prędkościach obrotowych silnika. Na badanym modelarskim silniku gwiazdowym o maksymalnej mocy $5,5 \mathrm{~kW}$ umieszczono śmigło dwułopatowe. Silnik umieszczono na stanowisku badawczym. Przeanalizowano budowę napędów lotniczych ze szczególnym uwzględnieniem modelarskich silników tłokowych, przyrządy do pomiaru poziomu dźwięku, normy i przepisy dotyczące emisji akustycznej z silników lotniczych oraz jak hałas lotniczy wpływa na zdrowie człowieka. W pracy również przedstawiono metody pomiarów akustycznych oraz elementy stanowiska badawczego. Wyznaczono poziom mocy akustycznej źródła w oparciu o pomiary poziomu ciśnienia akustycznego w 9 punktach pomiarowych na półkulistej powierzchni pomiarowej w przestrzeni zamkniętej zgodnie z normą PN - EN 3744. Przed zasadniczymi pomiarami zmierzono poziom ciśnienia akustycznego tła. Średnia moc akustyczna wytwarzana przez silnik ASP FS400AR na biegu jałowym $(2880 \mathrm{obr} / \mathrm{min})$ wynosi $96 \mathrm{~dB}$ a przy prędkości przelotowej (4740 obr/min) $105 \mathrm{~dB}$. Na podstawie wyników stwierdzono, że miernik ustawiony w punktach znajdujących się przed silnikiem, zarejestrował wyższy poziom mocy akustycznej niż punkty znajdujące się za modelarskim silnikiem tłokowym, natomiast najmniejsza moc akustyczna wyznaczona w czasie pomiarów znajduje się bezpośrednio nad silnikiem.

Słowa kluczowe: silnik modelarski, napędy lotnicze, moc akustyczna, hałas. 